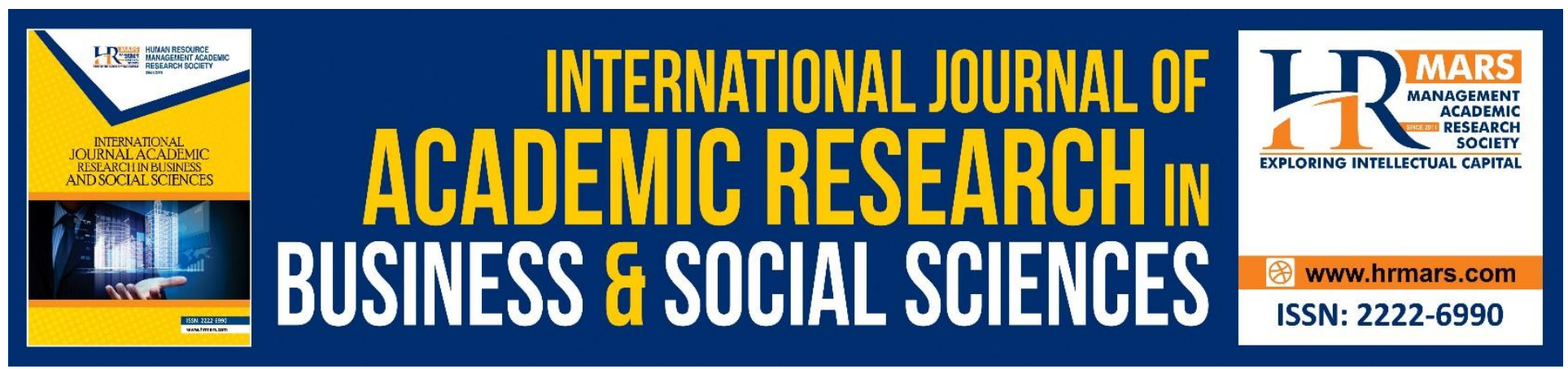

\title{
Waqf Assets Management: Harnessing Tool for Muslims' Welfare
}

Engku Muhammad Tajuddin Engku Ali, Nadhirah Nordin, Fadzli Adam \& Mutia Sobihah Abd Halim

To Link this Article: http://dx.doi.org/10.6007/IJARBSS/v8-i11/4907

DOI: $10.6007 /$ IJARBSS/v8-i11/4907

Received: 21 Oct 2018, Revised: 19 Nov 2018, Accepted: 24 Nov 2018

Published Online: 27 Nov 2018

In-Text Citation: (Ali, Nordin, Adam, \& Halim, 2018)

To Cite this Article: Ali, E. M. T. E., Nordin, N., Adam, F., \& Halim, M. S. A. (2018). Waqf Assets Management: Harnessing Tool for Muslims' Welfare. International Journal of Academic Research in Business and Social Sciences, 8(11), 348-354.

Copyright: () 2018 The Author(s)

Published by Human Resource Management Academic Research Society (www.hrmars.com)

This article is published under the Creative Commons Attribution (CC BY 4.0) license. Anyone may reproduce, distribute, translate and create derivative works of this article (for both commercial and non-commercial purposes), subject to full attribution to the original publication and authors. The full terms of this license may be seen at: http://creativecommons.org/licences/by/4.0/legalcode

Vol. 8, No. 11, 2018, Pg. 348 - 354

http://hrmars.com/index.php/pages/detail/IJARBSS

JOURNAL HOMEPAGE

Full Terms \& Conditions of access and use can be found at http://hrmars.com/index.php/pages/detail/publication-ethics 


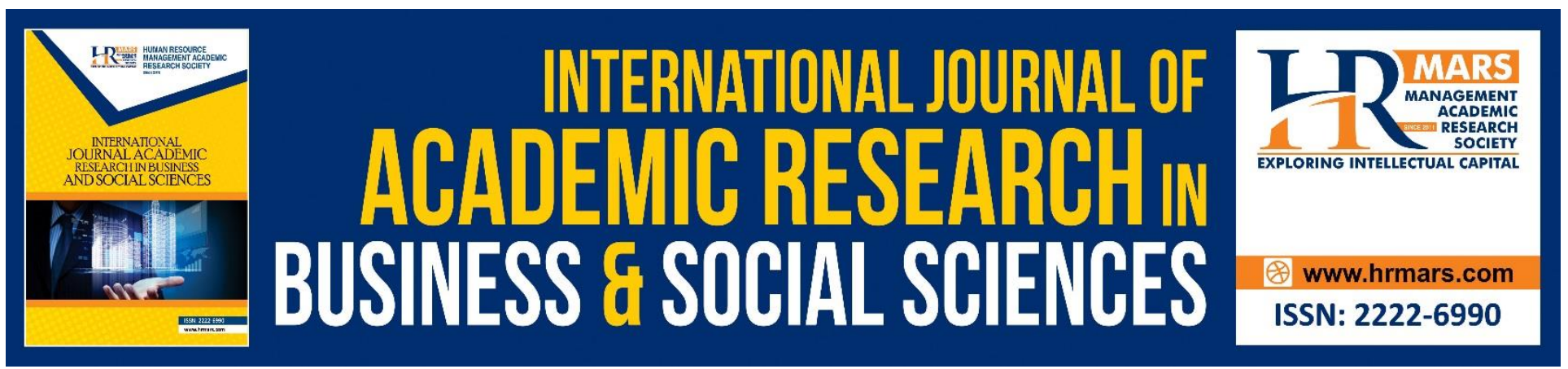

\title{
Waqf Assets Management: Harnessing Tool for Muslims' Welfare
}

\author{
Engku Muhammad Tajuddin Engku Ali, Nadhirah Nordin, Fadzli \\ Adam \& Mutia Sobihah Abd Halim \\ Universiti Sultan Zainal Abidin
}

\begin{abstract}
This article discusses the potential of waqf in harnessing the Muslims' welfare. A professional and effective administration of waqf is seen essential and regarded as a basic tool for a highly impact economic instrument in Islam. The varieties of waqf's objectives at the same time provide support for wide spreading religious and philanthropic activities. The potential of waqf institution strongly depends on Muslims's understanding towards waqf and significantly influenced by effective administration of its fund. Therefore, this writing aims to put forward a conceptual discussion on the meaning of waqf and its role in the Malaysian society. In addition, it is also importance to higlight the necessity to legislate a standardized law on waqf and its administration in developing Muslim socioeconomy.
\end{abstract}

Keywords: learning style; Muslim; philanthropic; Waqf; welfare

\section{INTRODUCTION}

Waqf is a practice where the ownership of an asset being hold in order to donate its benefit (AlJerjani, 2003). The main objective of waqf practice is to gain rewards from Allah and considered as one of highly encouraged practices in Islam (Al-Zuhaili, 1984). The ownership of a property will be removed from its donor once the property is donated as waqf. In other words, the previous owner cannot claim his property back and has no jurisdiction on it anymore (Al-Syirazi, 1996). The administration of waqf property under a professional institution has a big potential in developing and strenghtening the Muslims' economy (Latif \& Hassan, 2005). In Islamic history, waqf has been expanded from lands and orchards to mosques, schools, libraries, wells, roads, hospitals and orphanage (Said Sobri, 2008). Moroever, items that can be donated as waqf include immovable and movable properties. Modern shape of waqf has reformed from books, Quran and prayer mats to cash waqf, share waqf, corporate and others (Latif \& Hassan, 2005). All these methods of waqf do not only assist the government in establishing public facilities for the society but also contribute to the development of Muslims' socio-economics. 


\section{RESEARCH METHODOLOGY}

This is a qualitative study. The findings in a qualitative study were sought not from statistic or other quantification methods (Corbin \& Strauss, 2008). In a qualitative study, the researcher is the main instrument in collecting and analyzing the data whether in term of words or illustrations. Research was conducted in a natural background while an inductive analysis will be done in where the meaning given by participants is the main focus (Lebar, 2017). Data in this study are collected from primary and secondary resources including books, authentic articles, documents, artifacts, maps, pictures, and through interviews and observations (Awang, 2009), In this paper, data related to Waqf are sought from classic and contemporary books, closely related articles, artifacts, and documents such as paper reports and news archive. This data collection is vital in revealing how Waqf has been used as a tool in harnessing Muslim's welfare. The results of the collected data are analyzed accordingly. In this context, content analysis is used. Content analysis, as been quoted by Wilkinson and Birmingham (2003) from Krippendorff is a research technique for making replicable and valid inferences from data to their context.

\section{RESULTS AND DISCUSSION}

Waqf is not only an act of worship. It has its own potential in strengthening and uplifting the Muslim's socio-economic status. It can be done through a well-managed administration of waqf. Together with the zakat institutions, waqf is not only used to eliminate poverty and social problems but functions to enhance the income of the Muslims society.

Waqf activities have promising contribution to development of the nation physically by establishing education and health facilities and defense equipment. These can be achievable if the administration of waqf is properly reformed and institutionalized that can benefit many parties that can be taken from existing waqf fund (Kahf, 2003).

By practicing permanent nature of waqf, the ownership of Muslims towards land and real estate can be secured. The ownership of donated assets for waqf will never be transferred to anyone else and remains in the hand of the Muslims to ensure the authority of waqf assets will remain intact.

The permanent nature of waqf also resulted in the accumulation of waqf properties all over the Muslim lands. The varieties of their objectives at the same time provide support for widespread religious and philanthropic activities. These play important roles in the socio-political life of Muslim societies and communities (Kahf, 2011). Together with a proficient administration, proactive efforts must be taken to encourage Muslims society to practice waqf. An optimum involvement of Muslims in this practice will undoubtedly strengthen the Muslims' economy as stressed earlier in this article (Nik Hassan, 1999).

By donating cash waqf, for example, the Muslim community funds can be established that enable them to buy highly potential lands and real estates. These types of lands and real estates are usually sold at high price where only selected Muslims were affording to buy them. Therefore, cash waqf; help the Muslim generates sufficient funds to purchase the properties to elevate the income for the Muslim community. Hence, the same fund can be used to build hotels, commercial centers, shops and other physical infrastructure. The-generated income will then be disbursed for the importance of Muslims. The Grand Puteri Hotel in Terengganu, Malaysia, is an example of a waqf hotel that was set up to produce income for the benefit of waqf institution. 
The waqf has a vast potential, especially the cash waqf. The fund raised from cash waqf plays a vital role in developing the community. It can be utilized to strengthen small businesses and to fund new entrepreneurs who face difficulty to attain financial support from banks and other institutions. These entrepreneurs can be financially help if waqf institution is properly administered (Tohirin, 2010). At the same time the funding of cash waqf through qard al-hasan will eradicate the phenomena of illegal lenders. Lahsasna (2010) in his article is agreed with this function when he claims that cash waqf can be utilized to finance low risk loan in order to make profit and increase the fund. He also argues that cash waqf is a powerful mechanism in generating fund and investment that significantly contribute to improve industrial, financial system and economic development (Lahsasna, 2010).

Waqf fund can also be utilized for educational purposes which includes establishment of libraries, books, teacher and staff salaries and stipends for students. Waqf financing is not restricted to students of Islamic studies, but-also-conceal any related programmes. The practice of financing through waqf has promoted educational freedom that contributes the growth of educated scholars not necessarily produced from the rich and noble classes (Kahf, 2011). For example, the University of Al-Azhar is set to be an excellent example of how waqf fund can be used to fortify the education in the society.

Waqf fund also sustenance the government in providing infrastructures for the public as shown during the days of the Ottomans. Cizakca (2011) states that if the practiced of cash waqf is prolonged until now; greater achievements can be accomplished as what had happen in the days of the Ottomans empire. He further elaborate that waqf fund can also help to achieve modern microeconomic objective which is to decrease the government's expenditures, downsize the country's deficit budget and lessen government dependencies towards loan as a source of financing development projects. Health services which include hospitals construction and wages payment for physicians, apprentices and patients are clear examples of public infrastructures that can be developed through this fund. Another-justification is the formation of health waqf in Istanbul, called Shishli Children Hospital which was founded in 1898 (Kahf, 2011). In Malaysia, Johor Corporation Berhad (JCorp) has donated its share as waqf in three listed subsidiaries which were Kulim Bhd., KPJ Healthcare Bhd and Johore Land Bhd with net asset value amounted to RM200 million under the management of Kumpulan Waqaf Annur Bhd. The dividend generated from these shares will be reinvested, given to the State Islamic Religious Council and distributed for charity works for the benefits of Muslim's welfare in the country (Institut Kefahaman Islam Malaysia, 2014).

In another perspective, waqf is closely associated with philanthropic purposes and can serve the function of alleviating social problems. Many social problem occurrences are caused by financial glitches such as insufficient fund for marriage which can contribute to baby dumping. Adding to the above notion, young Muslims can be facilitated to secure stronger financial income for their marriage. Moreover, waqf fund can be channeled to help drug rehabilitation centers that are in need for financial support in order to carry out their programmes.

Proper administration of waqf fund will not only benefit human but also other living things such as animals as implemented in Damascus where specific waqf fund is allocated to treat abandoned animals (Kahf, 2011). The waqf system as stated here shows that the practice of waqf has 
varied and emerged significantly. Indeed Islam allows many forms of waqf practices as long as it complies with Islamic jurisprudence.

Bakar (1999) believes that the development of waqf property is compulsory. Waqf property must not be kept stagnant without any added value activities. The administrators of waqf (the nazirs and mutawallis) are obliged to develop these potential assets so it can benefit not only the beneficiaries but the Muslim society as a whole. This development can be done through direct investment in the stock market, unit trust or Islamic Banking investment scheme. Kahf (1998) supports this view when he suggested that the development of waqf asset should be done through Islamic instruments in the contemporary financial system.

This is one of many roles that can be played by the Islamic Banking in strengthening waqf. Islamic banks can help waqf institution for better asset investments because they usually have more expertise and experience in determining the best investment to breed these assets. On the other hand, most waqf institutions do not have enough expertise and experience to deal with this matter. Opening mudharabah accounts with any Islamic banks is an example of investment that can be adopted by waqf institutions. In addition, Islamic banks can also operate specific counters for those who want to donate their cash as waqf. Online transfer service, waqf through short message service (SMS), monthly salary deduction, direct debit order should be introduced to collect cash waqf.

Some other innovations to enrich the collection of cash waqf must be implemented. Islamic banks can allocate a special personal loan for those who need cash in order to establish waqf entity. This is done with a minimum or lower loan rate as a token of cooperation between Islamic banks and customers who wants to contribute something worthy to the society. This is in line with the Islamic teaching that urges Muslims to help each other's in doing good deeds.

Finally, Islamic banks themselves may utilize a portion of its annual profit as waqf. It is a sign of good initiative if the government takes a strong move to initiate this type of donation which is collected from banks, institutions or individuals and provides tax rebate from each completed donation. It is an essential effort to develop waqf assets particularly cash waqf which can be used to provide public infrastructures and strategically will help the government to reduce its-expenditure.

\section{CONCLUSION}

If modern economy is able to imitate the practice and administration of waqf like the days of the Ottomans, the macroeconomic objective will be achieved to attain a fair income distribution and reduce tax solely as the government source of income and reduce the tax burden on the society. The potential of waqf institution strongly depends on the understanding of the Muslims towards waqf and on effectiveness of the fund administration. Without these two variables, waqf institution cannot function to its maximize capacity. Therefore, in order to ensure the best impact of waqf on the Muslims' socio-economy status, it is crucial to comprehend the Muslims about the concept and functions of waqf. Besides, it is also essential to legislate a standard and complete law on waqf and its administration. In Malaysia, waqf is generally perceived as a charity act of worship and its concept is restricted to immoveable properties. However Muslims society needs to change this perception on waqf as it has been expanded to moveable properties such as cash, vehicles and scientific equipment. This reformed understanding and interpretation of the concept of waqf is very important to be understood by the government, financial institutions and society. It is an appropriate time for 
Muslims society to put their effort in supporting government's action in upholding waqf institution in order to increase Malaysian socio economy. In ensuring waqf can be utilized at its maximum capacity, the coverage of waqf item must be expanded from land and real estate to many other moveable properties. The succes model of waqf institutions as practiced in Singapore, Egypt and Kuwait should be considered as guideline by Malaysian authority to further develop local administration of waqf. In depth studies on rules and regulations enforced in these countries must be conducted to enable a standard and comprehensive waqf law to be drafted in Malaysia. The legislation of such law which can also be used as guideline by the state governments, will significantly contribute in enhancing the administration of waqf in Malaysia and at the same time will not violate the original intention of the waqif that is to worship Allah.

\section{ACKNOWLEDGEMENT}

Special thanks to Research Management, Innovation \& Commercialization Centre (RMIC) and University Sultan Zainal Abidin (UniSZA) for funding this research

\section{REFERENCES}

Latif, A.Z. \& Hassan, N. (2005). Potensi wakaf dalam menjana kemajuan umat Islam. Islam Hadhari: Pengukuhan Institusi Baitulmal dan Wakaf di Malaysia. Shah Alam: Universiti Teknologi Mara.

Al-Jerjani, H. A. (2003). Kitab al-ta'rifat. Qaherah: Maktabah al-Quran.

Al-Syirazi. (1996). Al-Muhazzab fi figh al-Imam al-Syafii. Qaherah: al-Halabi.

Al-Zuhaili, W. (1984). Al-Fiqh Islami wa Adillatuhu. Damsyiq: Dar al-Fikr.

Awang, I. (2009). Penyelidikan ilmiah amalan dalam pengajian Islam. Selangor: Kamil \& Shakir Sdn Bhd.

Bakar, M.D. (1999). Amalan institusi wakaf di beberapa negara Islam: Satu perbandingan. In: Konsep dan Perlaksanaan Wakaf di Malaysia. Kuala Lumpur: Institut Kefahaman Islam Malaysia.

Cizakca, M. (2011). Waqf in history and its implications for modern Islamic economies. In: Essential Readings in Contemporary Waqf Issues. Kuala Lumpur: CERT Publications.

Corbin, J. \& Strauss, A. (2008). Basics of qualitative research: Techniques and procedures for developing grounded theory (3rd ed.). Thousand Oaks, CA: Sage.

Institut Kefahaman Islam Malaysia, IKIM. (2014, August 1). Wakaf tunai: Pendekatan terbaik untuk mewakafkan harta masa kini. Berita Harian. Retrieved from http://www.ikim.gov.my/index.php/ms/berita-harian/7541-wakaf-tunai-pendekatan-terbaikuntuk-mewakafkan-harta-masa-kini

Kahf, M. (1998). Financing the development of Awqaf property. Proceedings of Seminar on Development of Awqaf. IRTI: Kuala Lumpur.

Kahf, M. (2003). The role of waqf in improving the ummah welfare. Proceedings of the International Seminar on Waqf and Private Legal Body, Medan, Indonesia, 6-7 January 2003 (pp. 1-26). Islamic University of North Sumatera.

Kahf, M. (2011). Waqf and its sociopolitical aspect. In: Essential Readings in Contemporary Waqf Issues. Kuala Lumpur: CERT Publications. 
Lahsasna, A. (2010). The role of cash waqf in financing micro and medium sized enterprises (MME). Proceedings of the Seventh International Conference on the Tawhidi Epistimology. Bangi: Zakat and Waqf Economy.

Lebar, O. (2017). Penyelidikan kualitatif pengenalan kepada teori dan metode. Perak: Penerbit Universiti Pendidikan Sultan Idris.

Hassan, N.M. (1999). Konsep dan pelaksanaan wakaf di Malaysia. Kuala Lumpur: Institut Kefahaman Islam Malaysia.

Sobri, I. (2008). Al-Waqf al-Islami Baina al-Nazariyyah wa al-Tatbiq. Urdun: Dar al-Nafais.

Tohirin, A. (2010). The Cash Waqf For Empowering The Small Businesses. Proceedings of the Seventh International Conference on the Tawhidi Epistimology. Bangi: Zakat and Waqf Economy.

Wilkinson, D. \& Birmingham, P. (2003). Using research instruments: A guide for researchers. NY: Routledge Falmer. 